\author{
G. Klymenko, Y. Vasylchenko, \\ V. Kvashnin, Kramatorsk, Ukraine
}

\title{
MODELING OF CUTTING TOOLS WEAR FOR LATHES
}

\begin{abstract}
A mathematical model to estimate the average number of parts, processing which is possible to achieve the criterion of maximum allowable wear on the back of the cutter heavy lathe, and the maximum allowable amount of tool material, removed from the front surface of the tool. Experimental equipment for measuring tool wear has been developed. Insert wear curves derived from industrial test results. Confirmation of the adequacy of the models of the instrument gives a possibility of their adjustment to the basic criteria of their dullness.
\end{abstract}

Keywords: wear; contact stress; cutting edge; cutting temperature; adhesive wear; the adequacy of the models.

The tool wear of cutting tools has a very strong impact on the product quality as well as on the efficiency of the machining processes. Despite the current high automation level in the machining industry, a few key issues prevent complete automation of the entire turning process. One of these issues is tool wear, which is usually measured off the machine tool. A well-known model for the tool wear rate was developed by Usui et al (Usui\& Shirakashi, 1984), and it is based on the idea of contact mechanics and wear. The most famous tool life model is Taylor's model in which the tool life depends mainly on the cutting speed and a constant determined by materials of the tool and the workpiece, feed rate, etc. (Taylor, 1906). In the past over thirty years, much work has been contributed to the tool wear modeling [1-6].

While working on the details of heavy lathes main types of fault-alloy cutters are wearing them on the front and back surfaces, as well as fatigue damage cutting plates. Determination of maximum permissible values of wear on the back surface were carried out based on economic criteria.

For practical use have a value of mathematical models to estimate the average number of parts, which was processed to reaching the criterion of wear.

Evaluation of resistance of cutting tool criterion for maximum allowable wear on the rear surface.

Developing a model to assess the average number of parts, processing, which is possible to achieve the criterion of maximum allowable wear on the rear surface is made to the following basic assumptions:

- criterion of maximum allowable adhesion wear on the back of the formation of a high wear areas $\left[h_{z p}\right]=1,2 \mathrm{~mm}$; 
- basic mechanism of cutting tool wear on the back of the adhesion mechanism is;

- average temperature of the material the instrument is fixed for the whole region back surface contact with the processed material;

- stress of the cutting tool is a flat;

- tool material in contact with the workpiece the tool is characterized by a constant value for the whole region stresses fluidity $R_{c M}$;

- number of parts, processing which is possible to achieve the maximum allowable height of platform wear $\left[h_{z p}\right]$ is:

$$
N_{0.1}=\frac{\left[\mathrm{h}_{z p}\right]}{h_{z p}},
$$

where $h_{z p}$ - increased wear platform for processing one part.

Based on studies of normal contact pressure distribution on the back of the instrument $q(\mathrm{x})$ can be represented by dependence:

$$
q(\mathrm{x})=\mathrm{q}_{\max . z}\left(1-\sqrt{\frac{x}{h_{z p}}}\right),
$$

where $h_{z p}$ - width areas of physical contact in this case - wear areas; $x$ distance from the cutting edge cutter; $\mathrm{q}_{\max . z}$ - maximum contact pressure at the back of the:

$$
q_{\max . \mathrm{z}}=2 \tau_{\phi}(1,3 \pm \gamma) \pm \tau_{\phi} \sin 2 \gamma
$$

(plus sign corresponds to negative front angles);

where $\tau_{\phi}$ - tension changes in a layer that trimmed, with the average temperature at the site contact the back of the instrument with the processed material. To Determine the value used $\tau_{\phi}$ dependence:

$$
\tau_{\phi}=0,72 R_{\theta} \cdot 6^{0.6 \delta_{5}},
$$

where $R_{\theta}$ - ultimate strength of the material processed at an average temperature at the site of contact; $\delta_{5}$ - elongation of the material processed at an average temperature at the site of contact. To evaluate the quantities $R_{\theta}, \delta_{5}$ used depends obtained on the basis of statistical data processing:

$$
R_{\theta}(\Theta)=R_{\theta_{0}} \exp \left(a_{1}\left(\Theta_{0}-\Theta\right)\right), \delta_{5}(\Theta)=\delta_{5_{0}} \exp \left(b_{1}\left(\Theta-\Theta_{0}\right)\right),
$$


where $\Theta$ - average temperature cutting; $R_{\theta_{0}}, \delta_{5_{0}}$ - tensile strength and elongation of the material processed at a temperature test $\Theta_{0}=700^{\circ} C ; a_{1}, b_{1}-$ coefficients determined by the method of least squares.

The average contact pressure at the back of the instrument can measure the expression $q$ :

$$
q=\frac{1}{h_{z p}} \int_{0}^{h_{m}} q_{\max . z}\left(1-\sqrt{\frac{x}{h_{z p}}}\right) d x .
$$

To determine the average temperature dependence of cutting used by the author, obtained by statistical progressing of experimental data:

$$
\Theta=a_{1} v^{a_{2}} s^{a_{3}} t^{a_{4}},
$$

where $a_{1}, a_{2}, a_{3}, a_{4}$ - calculated ratios determined by the method of least squares.

To determine the number of the parts to achieve the criterion of maximum allowable adhesion wear on the back of the take that amount of material $d$, removed from the back of the instrument for the elementary time interval $d \tau$ physical contact with the workpiece material back of the cutter, can be estimated from geometrical considerations:

$$
d Q=b\left(h \cdot d h \cdot \tan \alpha+\frac{1}{2} d h^{2} \cdot \tan ^{2} \alpha \cdot \tan \gamma\right) ; b=\frac{t}{\sin \varphi},
$$

where $h$ - altitude areas of wear, which corresponds to the moment of time $\tau ; d h$ - increase in areas of wear during $d \tau ; \gamma, \alpha, \varphi$ - under the front corner and rear corner of the main corner in terms of the instrument; $t$ - depth of cut.

On the other hand, the volume of material removed from the rear surface during $d \tau$, measured the expression:

$$
d Q=P_{u} v \eta \delta b \cdot d \tau, \eta=\frac{q}{q^{*}}
$$

where $P_{u}$ - the likelihood that the zone of adhesion failure of communication is not in the treated material, and material of the instrument; $v$ - speed cutting; $\delta$ - thickness of which is the destruction of products bearing adhesive ties: $\delta \cong 3 \cdot 10^{-5} . .5 \cdot 10^{-9} \mathrm{~m} ; \quad \eta-$ the relative share areas of plastic surface microirregularity crumple in contact with the back of the instrument of processed material; $q^{*}-$ maximum pressure required to crumple the full surface microirregularity processed material at the site of contact, estimated the expression: 


$$
q^{*}=2,5 R_{e}(1-\mu),
$$

where $R_{e}$ - meaning limits yield of processed materials in accordance with the average temperature in the cutting zone; $\mu$-constant friction.

If the average pressure at the site of contact, the workpiece material with the rear surface instruments such that the value $\eta>1$, we adopted $\eta=1$. Size $P_{u}$ can be estimated from the ratio of the critical crack lengths Hryffitsa that triggered the destruction of adhesion due:

$$
P_{u}=\frac{l_{u}}{l_{u}+l_{m}}, \frac{l_{u}}{l_{m}}=\frac{R_{m}^{2}}{R_{u}^{2}},
$$

where $l_{u}, l_{m}$ - under the critical length of cracks in the surface layers of tool and workpiece material; $R_{u}, R_{m}$ - tensile strength of the material and tool material processed at an average temperature at the site of contact. Taking the tool material and workpiece material hard plastic, the expression $\frac{R_{m}^{2}}{R_{u}^{2}}$ can be replaced by $\frac{R_{e}^{2}}{R_{e u}^{2}}$, where $R_{e}, R_{e u}$ - border fluidity workpiece material and tool material at an average temperature at the site of contact, respectively. To determine the value of $R_{e}$ used the dependence obtained by statistical processing of experimental data:

$$
R_{e}(\Theta)=R_{e_{0}} \cdot \exp \left(b\left(\Theta_{0}-\Theta\right)\right),
$$

where $\Theta$ - the average temperature at the site of contact; $R_{e_{0}}$ - the boundary strength of the material processed at a temperature test $\Theta_{0}=700^{\circ} \mathrm{C} ; b-$ estimated coefficient determined by the method of least squares.

To determine the value of $R_{e u}$ used dependence obtained by statistical processing of experimental data:

$$
R_{e u}=1,1 R_{T}\left(\frac{\Theta_{p}}{\Theta}\right)^{S} \operatorname{arsh}\left(\frac{\dot{e} \cdot e}{\dot{e}_{0} \cdot e_{0}}\right), \Theta \geq \Theta_{p},
$$

where $\dot{e}_{0}, e_{0}$ - intensity of deformation speed and intensity of accumulated strain during mechanical testing instrument; $R_{T}$ - boundary strength of the material instrument at ambient temperature; $\mathrm{S}$ - constant characteristic of the tool material. If the temperature does not exceed $\Theta$ cutting temperature early intensive removed $\Theta_{p}$, instrumental material, it shall $R_{e u}=R_{T}$.

Comparing expressions (8) and (9) and respect for value $d h^{2}$, as the second largest order little, after the integration date was changing altitude areas of wear from time to time contact: 


$$
h_{z p}=\sqrt{\frac{2 v \delta \eta P_{u}}{\tan \alpha}}, \tau=\frac{l}{n S},
$$

where $\tau$-time of processing one part, $n$-speed spindle.

After substituting the values of $\eta$ and $P_{u}$ obtained:

$$
h_{z p}= \begin{cases}\sqrt{\frac{2 \cdot q_{\max } \cdot v \cdot \tau \cdot \delta}{4,5 \cdot \operatorname{tg} \alpha \cdot(1-\mu)} \cdot \frac{R_{e}}{R_{e}^{2}+R_{e u}^{2}}} & \text { if } \frac{q_{\max }}{7,5 \cdot R_{e}(1-\mu)}<1 \\ \sqrt{\frac{2 \cdot v \cdot \tau \cdot \delta \cdot R_{e}^{2}}{\operatorname{tg} \alpha \cdot\left(R_{e}^{2}+R_{e u}^{2}\right)}} & \text { if } \frac{q_{\max }}{7,5 \cdot R_{e}(1-\mu)} \geq 1\end{cases}
$$

Then the number of parts, processing of which is available until a maximum allowable height of areas on the back of the depreciation is:

$$
N_{0.1}= \begin{cases}{\left[\mathrm{h}_{z p}\right] \cdot \sqrt{\frac{3,75 \cdot \tan \alpha(1-\mu)\left(R_{e}^{2}+R_{e u}^{2}\right)}{q_{\max } \cdot v \cdot \tau \cdot \delta \cdot R_{e}}}} & \text { if } \frac{q_{\max }}{4,5 \cdot R_{e}(1-\mu)}<1 \\ {\left[\mathrm{~h}_{z p}\right] \cdot \sqrt{\frac{\tan \alpha\left(R_{e}^{2}+R_{e u}^{2}\right)}{2 \cdot v \cdot \tau \cdot \delta \cdot R_{e}}}} & \text { if } \frac{q_{\max }}{4,5 \cdot R_{e}(1-\mu)} \geq 1\end{cases}
$$

The main mechanism of wear of cutting tools on the front surface are adhesion mechanism.

As a criterion of maximum allowable wear of the front surface is proposed to adopt the appearance of the front surface of the hole cutter wear depth $\left[h_{n n}\right]$.

Average number of blocks and treatment are possible until a maximum allowable depth of the hole wear, can be evaluated dependence:

$$
N_{0.2}=\frac{[Q]}{Q},
$$

where $[Q]$ - the maximum allowable amount of tool material, removed from the front surface of the tool that meets $\left[h_{n n}\right] ; Q$ - volume of tool material, removed from the front surface of the tool during the processing of one part.

Value $[Q]$ is determined from geometric considerations the following expression:

$$
[Q]=f b, f=\frac{R^{2} \alpha-\left(R-\left[h_{n n}\right]\right) l}{2}, R=\frac{\left[h_{n n}\right]}{2}+\frac{l^{2}}{8\left[h_{n n}\right]},
$$

where $l$ - length of the hole, $b$ - width of the contact front surface of cutting tools with workpiece: 


$$
b=\frac{t}{\sin \varphi} .
$$

The volume of material $\partial Q$, which is removed by an elementary interval of time of physical contact with the chip front surface of the tool is determined by the equation $d \tau$ :

$$
\partial Q=P_{u} v_{c} \eta \delta b \cdot d t, v_{c}=\frac{v}{\xi},
$$

where $P_{u}$ - the likelihood that the zone of adhesion failure of communication is not in the treated material, and material tools, assessments expression (13); $v_{c}-$ speed chips on the front surface of the tool; $v$ - speed cutting; $\xi$ - coefficient of shrinkage of the chip; $\delta$ - thickness of the layer from which the products bearing the destruction of adhesive contacts: for most metals and alloys $\delta \cong 3 \cdot 10^{-10} . .5 \cdot 10^{-9}$ $\mathrm{m} ; \eta$ - the relative share of regions full of plastic crumple microroughness chip surface in contact with the chip front surface:

$$
\eta=\frac{q}{q^{*}}
$$

where $q$ - the average pressure at the site of contact; $q^{*}$ - average pressure required to crumple the full surface microroughness processed material on this site, estimated expression (10).

Based on studies of normal contact pressure distribution on the back of the instrument $q(x)$ can be represented by dependence:

$$
q(x)=q_{\max . n}\left(1-\sqrt{\frac{x}{l_{k}}}\right),
$$

where $l_{k}$ - chip contact length on the front surface:

$$
l_{k}=a(\xi(1-\tan \gamma)+\sec \gamma), a=s \cdot \sin \varphi ;
$$

$q_{\text {max.n }}$ - maximum normal pressure on the front surface:

$$
q_{\max . n}=2 \tau_{\varphi}(1,3-\gamma) \text {. }
$$

The average value of normal pressure on the site of contact is:

$$
q=\frac{1}{l_{k}} \int_{0}^{l_{k}} 2 \tau_{\varphi}(1,3-\gamma)\left(1-\sqrt{\frac{x}{l_{k}}}\right) d x .
$$

The volume of material instrument removed from the front surface of the tool during the processing of one part $\tau$, is recognized by dependence: 


$$
Q=\int_{0}^{\tau} P_{u} v_{c} \eta \delta b \cdot d t
$$

Then, taking into account (23), (24):

$$
Q=\frac{R_{e}^{2}}{R_{e}^{2}+R_{e u}^{2}} \frac{v}{\xi} \frac{1}{q^{*}} \delta \frac{t}{\sin \varphi} \frac{1}{l_{k}} \int_{0}^{l_{k}} \int_{0}^{\tau} q_{\max }\left(1-\sqrt{\frac{x}{l_{k}}}\right) d x d t .
$$

On the assumption that the value of $P_{u}, v_{c}, \delta, b$ insignificant change in contact time, according to a theorem on the average integral obtained:

$$
Q= \begin{cases}\frac{R_{e}}{R_{e}^{2}+R_{e u}^{2}} \frac{v}{\xi} \delta \frac{q_{\max } t \tau}{4,5 \sin \varphi(1-\mu)} & \text { if } \frac{q_{\max }}{4,5 \cdot R_{e}(1-\mu)}<1 \\ \frac{R_{e}^{2}}{R_{e}^{2}+R_{e u}^{2}} \frac{v}{\xi} \delta \frac{t \tau}{\sin \varphi} & \text { if } \frac{q_{\max }}{4,5 \cdot R_{e}(1-\mu)} \geq 1\end{cases}
$$

Then the number of parts, processing which is possible to achieve the criterion of maximum permissible adhesion wear on the front surface is:

$$
N_{0.2}= \begin{cases}\frac{[Q]\left(R_{e}^{2}+R_{e u}^{2}\right) \xi \cdot 4,5 \sin \varphi(1-\mu)}{R_{e} v \delta q_{\max } t \tau} & \text { if } \frac{q_{\max }}{4,5 \cdot R_{e}(1-\mu)}<1 \\ \frac{[Q]\left(R_{e}^{2}+R_{e u}^{2}\right) \xi \cdot \sin \varphi}{R_{e}^{2} v \delta t \tau} & \text { if } \frac{q_{\max }}{4,5 \cdot R_{e}(1-\mu)} \geq 1\end{cases}
$$

Evaluation of resistance of cutting tool criterion for maximum allowable wear size.

For the finishing details stochastic equation has the form of wear:

$$
\frac{d x}{d t}+d x=N(t)
$$

Failure occurs when the details of its size to achieve maximum permissible value $x_{\max }$, which happens after a random interval of tool $t=T_{n}$. Maximum permissible value of the parameter $x_{\max }$ determined from the condition of normal operation of the instrument. Operating time to failure $T_{n}$ is a function of random arguments tool wear rate of change of $C$, i.e. $T_{n}=f(\mathrm{C})$. Failure occurs tool for achieving detail maximum permissible value $x_{\max }$, what happens after a random period of time to process it. 
Processed on a machine part has size, which tolerance is within the boundaries $x_{\min }-x_{\max }$. With increasing wear on the back of the instrument the size of parts changed. In average (Fig. 1) size of the parts is beyond the tolerance only after an interval time $T_{4}$. But during work tool in the initial period of operation from $T_{1}$ to $T_{2}$ there is a danger for details, treated on the upper field tolerance, then the reliability of their increases. Excess of the tolerance field components finished to the lower limit of tolerance is possible at time $t=T_{3}$, with $T_{2}<T_{3}, T_{3}<T_{4}$, as

$$
(a, b)=\left(\frac{C}{\lambda} ; \frac{C}{\lambda}+\Delta_{\max }\right)=\left(x_{\min }, x_{\max }\right) .
$$

Expected value and variance of dimensional stability of the instrument from the initial values gap $\Delta_{0}$, constant velocity component wear $C$ and the coefficient of proportionality $\lambda: W\left(\Delta_{0}\right)=\delta\left(\Delta_{0}-\Delta_{03}\right)$ :

$$
W(C)=\delta\left(C-C_{3}\right), W(\lambda)=\delta\left(\lambda-\lambda_{3}\right) .
$$

in this case, the probability density of the coordinates $\mathrm{x}$ in equation (30) at the initial time $t=0$ is a delta-like function, i.e.

$$
W_{0}(x)=\delta\left(x-x_{0}\right)=\delta\left(x-\frac{C_{3}}{\lambda}-\Delta_{03}\right) .
$$

The probability that a random $x$ coordinate at the time $t$ reaches the limits of the interval $\left(x_{\min }, x_{\max }\right.$ ) through $P x_{\min }, x_{\max }(t, x)$. For continuous Markov process that can take wear and tear, the specific probability satisfies the equation:

$$
\frac{\partial P x_{\min , \max }}{d t}=K_{1}\left(x_{0}\right) \frac{\partial P x_{\min , \max }}{d x_{0}}+\frac{1}{2} K_{2}\left(x_{0}\right) \frac{\partial^{2} P x_{\min , \max }}{d x_{0}^{2}},
$$

with initial conditions $P x_{\min , \max }\left(0, x_{0}\right)=0$ and boundary conditions $P x_{\min }, x_{\max }\left(t, x_{\min }\right)=P x_{\min }, x_{\max }\left(t, x_{\max }\right)=1$.

$$
\lim _{t \rightarrow \infty} P x_{\min }, x_{\max }(\mathrm{t}, \mathrm{x})=1 \text {. }
$$

Coefficients $K_{1}\left(x_{0}\right), K_{2}\left(x_{0}\right)$ in equation (34) as determined in accordance with expectation rate depreciation in the initial time and a spectral density of the process $N(t)$ by the formula: 


$$
K_{1}\left(x_{0}\right)=C+\lambda \Delta_{0} ; K_{2}\left(x_{0}\right)=\frac{1}{2} \sigma_{N}^{2} .
$$

Marked the one-dimensional moments in time limits to achieve a

$$
T_{n}=T_{n}\left(x_{\min }, x_{0}, x_{\max }\right)=\int_{0}^{\infty} t^{n} \frac{\partial P x_{\min }, x_{\max }}{\partial t} d t,
$$

Equation (34) differentiating both parts by $t$, multiplying result by $\exp (j v t)$ and then integrating in $t$ from 0 to $\infty$, returned the following equation for the characteristic function:

$$
\begin{gathered}
-j \vee \Theta x_{\min }, x_{\max }=K_{1}\left(x_{0}\right)=\frac{\partial \Theta x_{\text {min }}, \mathrm{x}_{\max }}{d x_{0}}+\frac{1}{2} K_{2}\left(x_{0}\right) \frac{d^{2} \Theta x_{\min }, x_{\max }}{d x_{0}^{2}}, \\
\Theta x_{\min }, x_{\text {max }}\left(j v, x_{0}\right)=-\int_{0}^{\infty} \frac{\partial}{\partial t} P x_{\text {min }}, x_{\text {max }}(\mathrm{t}, \mathrm{x}) \mathrm{e}^{j v t} d t .
\end{gathered}
$$

Equation (35) to find the first moments of time reaching the limits of tolerance parts and used to determine stability of the instrument (Fig. 1).

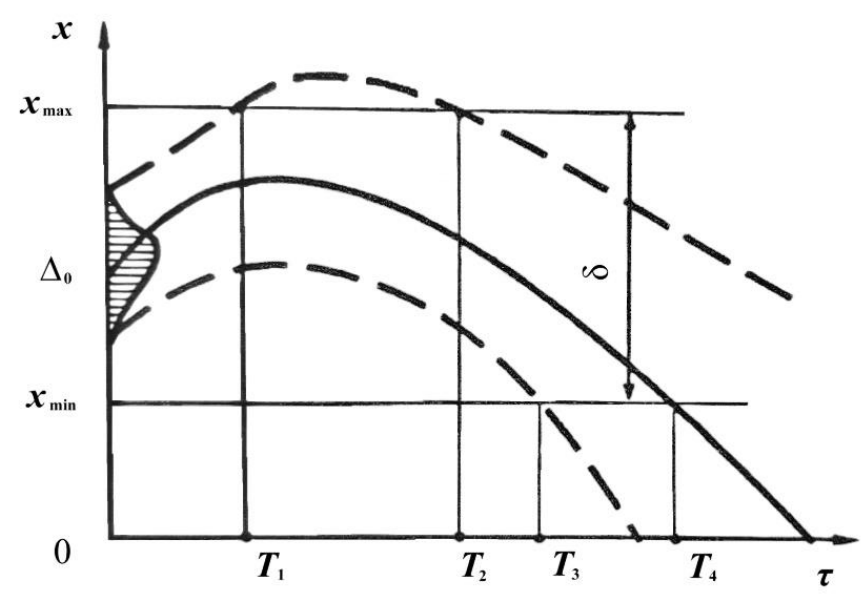

Figure 1 - Moments of time reaching the limits of tolerance parts

To check the adequacy of the models developed experimental unit for measuring tool wear. Based on performance testing tools in industrial conditions obtain wear curves cutting plates, their example shown in Fig. 2. The probability of adequacy of mathematical models is 0.71 . 


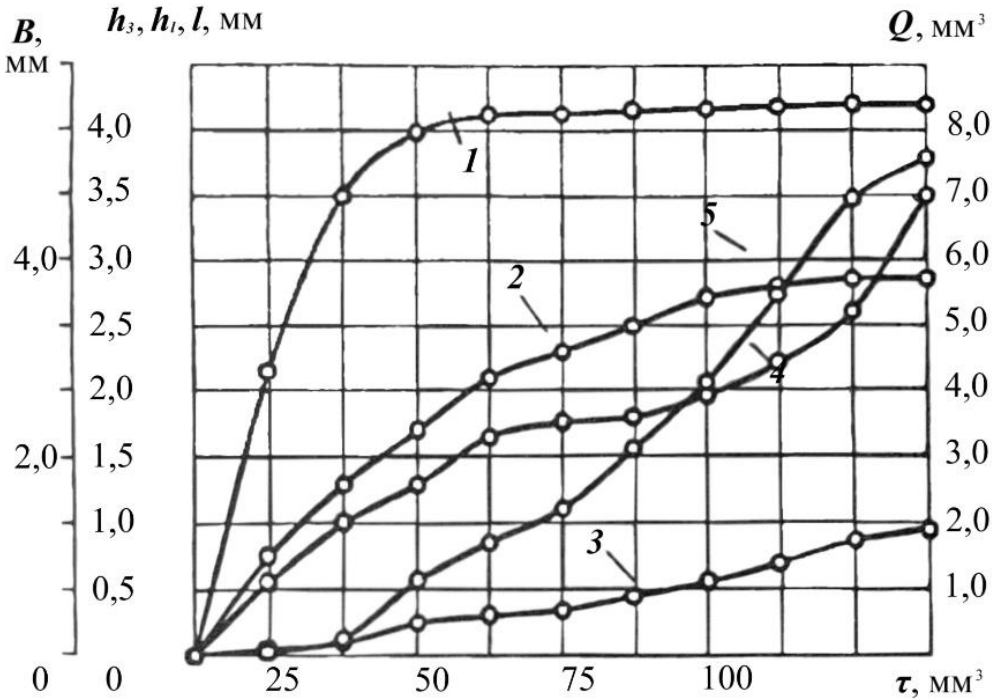

Figure 2 - Crooked wear plate cutting SNMG 380932

(1 - width, 2 - length, 3 - deep hole, 4 - width chamfer wear on the rear surface, 5 the amount of material the tool is withdrawn from the front surface)

On the basis of students have developed analytical calculation based cutting tool wear on the front and back surfaces of the parameters of the operation, which averages to estimate the period of stability instrument, proposed method of determining the dimensional stability of the instrument with a given probability (for finding the size of workpieces in a given field admission), which depends on tool wear during the finishing details.

References: 1. Palanisamy, Ponnusamy \& Shanmugasundaram, S. (2008). Modelling of tool wear and surface roughness in hard turning using regression and artificial neural network. International Journal of Machining and Machinability of Materials. 4. 10.1504/IJMMM.2008.020912. 2. Čerče, L., Pušavec, F., \& Kopač, J. (2015). A New Approach to Spatial Tool Wear Analysis and Monitoring. Strojniški vestnik - Journal of Mechanical Engineering, 61(9), 489-497. doi: http://dx.doi.org/10.5545/sv-jme.2015.2512. 3. P. Huang and W. B. Lee, "Cutting Force Prediction for Ultra-Precision Diamond Turning by Considering the Effect of Tool Edge Radius," International Journal of Machine Tools and Manufacture 109 (October 2016): 1-7, https://doi.org/10.1016/j.ijmachtools.2016.06.005. 4. Zhang X, Zheng G, Cheng X, Хu R, Zhao G, Tian Y. Fractal Characteristics of Chip Morphology and Tool Wear in HighSpeed Turning of Iron-Based Super Alloy. Materials (Basel). 2020;13(4):1020. Published 2020 Feb 24. doi:10.3390/ma13041020. 5. Maruda R.W., Krolczyk G.M., Nieslony P., Wojciechowski S., Michalski $M$., Legutko $S$. The influence of the cooling conditions on the cutting tool wear and the chip formation mechanism. J. Manuf. Process. 2016;24:107-115. doi: 10.1016/j.jmapro.2016.08.006. 
[CrossRef] [Google Scholar]. 6. Hao Z.P., Fan Y.H., Lin J.Q., Yu Z.X. Wear characteristics and wear control method of PVD-coated carbide tool in turning Inconel 718. Int. J. Adv. Manuf. Technol. 2015;78:1329-1336. doi: 10.1007/s00170-014-6752-0. [CrossRef] [Google Scholar].

\author{
Галина Клименко, Яна Васильченко, \\ Владислав Квашнін, Краматорськ, Україна
}

\title{
МОДЕЛЮВАННЯ ЗНОШУВАННЯ РІЗАЛЬНИХ ІНСТРУМЕНТІВ ДЛЯ ТОКАРНИХ ВЕРСТАТІВ
}

\begin{abstract}
Анотація. Для визначення періоду стійкості інструменту, а також базових показників процесу його експлуатаиії, які характеризують зношування інструменту, розроблено математичні залежності зношування різального інструменту по передній та задній поверхням від параметрів його експлуатації на важких верстатах. Для перевірки адекватності моделей зношування проведені експериментальні дослідження зміни геометричної форми різального клину методом неруйнівного контролю за допомогою спеціально розробленого приводу. Вимірювались геометричні розміри лунки зношування по передній поверхні. В результаті досліджень проаналізовані види відмов інструменту та побудовано криві зношування різальних пластин в умовах виробництва. Запропоновано методику розрахунку величин зношування контактних передньої та задньої поверхонь на основі енергетичної теорії зномування, щуо дозволяє визначити такі характеристики зношування різия, як величина й форма фаски зношування на його задній поверхні, величина радіального зношування, геометричні розміри й форма лунки зношування на його передній поверхні. Розроблено математичну модель для очінки середньої кількості деталей, при обробиі яких, можливе досягнення критерію максимально допустимого зносу на задній поверхні різия важкого токарного верстату та максимально допустимої кількості інструментального матеріалу, що знімається передньою поверхнею інструменту. Величина розбіжності розрахованої форми зноченого різального клину від певної, здобутої експериментальним иляхом, не перевищує 10\%. Підтвердження адекватності моделей зношування інструменту дає змогу використовувати їх для розрахунку базових показників критеріїв його затуплення. Запропонована методика визначення розмірної стійкості різального інструменту з заданною імовірністю.
\end{abstract}

Ключові слова: зношування; контактне напруження; ріжуча кромка; температура різання; адгезійне зношування; адекватність моделі. 